\title{
The Nucleus-Estate and Smallholder Partnership towards Export Competitiveness of Timor Leste Coffee
}

\section{Belandia da Costa Graciana1*, I Gusti Agung Ayu Ambarawati², Dwi Putra Darmawan², I Wayan Budiasa ${ }^{2}$}

${ }^{1}$ Doctoral Program in Agricultural Science, Faculty of Agriculture, Udayana University, Denpasar, Indonesia

${ }^{2}$ Faculty of Agriculture, Udayana University, Bali, Indonesia

Email: ^bellagenelvia@gmail.com, annie.ambarawati@gmail.com

How to cite this paper: da Costa Graciana, B., Ambarawati, IG.A.A., Darmawan, D.P. and Budiasa, IW. (2019) The Nucleus-Estate and Smallholder Partnership towards Export Competitiveness of Timor Leste Coffee. Modern Economy, 10, 1655-1670. https://doi.org/10.4236/me.2019.107108

Received: May 28, 2019

Accepted: July 7, 2019

Published: July 10, 2019

Copyright (อ 2019 by author(s) and Scientific Research Publishing Inc. This work is licensed under the Creative Commons Attribution International License (CC BY 4.0).

http://creativecommons.org/licenses/by/4.0/

\begin{abstract}
Coffee is one of the superior agricultural commodities in Timor Leste. It is cultivated by majority of smallholder farms. The Cooperativa Cafe Timor (CCT) is the biggest company partner with local coffee farmers in Timor Leste that facilitates farmers to apply good agricultural practices to yield better production and quality, in turn higher price. The CCT accounts for about 65 percent of Timor Leste's coffee exports. This study aims to firstly describe the type of partnership between coffee farmers and the CCT in Timor Leste. Secondly, to examine the competitiveness of Timor Leste's coffee in the world market with selected producing countries. Based on the rights and obligation between farmers and the CCT, it can be categorized as a Nucleus-estate and Smallholder (NES) partnership model developed by the CCT and the local coffee farmers. Results from Revealed Comparative Advantage (RCA) show that Timor Leste is not able to compete with Vietnam and Indonesia, but it competes with the Philippines and Thailand. Nonetheless, Timor Leste coffee is able to compete in the world market in terms of its quality with organic certification.
\end{abstract}

\section{Keywords}

Nucleus-Estate Small Holder Partnership, RCA, Cooperativa Café Timor

\section{Introduction}

Coffee is an extremely important agricultural commodity, produced in about 80 tropical countries, with an estimated 125 million people depending on it for their livelihoods in Latin America, Africa, and Asia, with an annual production 
of about nine million tons of green beans. Coffee is mostly grown by poor smallholder farmers, makes up about $80 \%$ of the country's agricultural exports [1] [2]. Coffee is also of a global importance, ranking second to petroleum in the world commodity trade. Agriculture often becomes a strength which contributes to the economic development in many developing countries. It contributes almost half of the income earned by the developing countries through their exported commodities including coffee [3].

In Timor Leste, coffee is one of the superior agricultural export commodities that contribute by $80 \%$ to the non-oil exported commodities. Data from the Ministry of Agricultural Affairs of Timor Leste in 2017 showed that around 55,714 families are coffee growers. Most of them come from small families living in the rural areas. They are highly dependent on the sales from coffee beans for daily needs. The main coffee producers in Timor Leste are Ermera District (27,210 families), Manufahi District (11,420 families), Liquiça and Ainaro Districts (7232 families respectively). These four areas live about 95 percent of coffee farmers in Timor Leste [4].

Timor Leste has two species of coffee; they are Arabica and Robusta. The Arabica coffee contributes $80 \%$, the Robusta coffee and the mixed coffee (Arabica and Robusta) contributes $20 \%$. The Robusta coffee is typically cultivated at a height of 600 to 1000 meters and the Arabica at a height of 1000 to 2000 meters. The coffee harvest season runs for four to five months starting from May to October yearly. The Arabica coffee has superior quality in terms of aroma, variety of taste and chemical composition, allowing an extraordinary reputation in several markets and obtaining premium prices [5].

The majority of coffee farmers in Timor Leste is not able to access the international market due to limited production facilities, lack of information to the market and capital. Accordingly, farmers need assistance from any institutions to sell their products directly to intermediary traders or middlemen, wholesalers or exporters to attain higher price. Farmers also sell coffee in the local market as an addition income for their family daily needs. One of the big companies or exporters that have been buying and selling coffee in Timor Leste is The Cooperativa Café Timor (CCT). The CCT has involved in the processing and marketing of organic coffee in Timor Leste since 2000 and it has been controlling about 65 percent of the Timor Leste's coffee exports. Other coffee exporters are Timor Global and Timorcorp.

CCT is the largest partner company in Timor Leste that helps coffee farmers to gain access to the international markets. CCT helps farmers to produce coffee in better management and in accordance with Good Agriculture Practices (GAP) in the form of partnership. The use of good production methods has led to increased product quality and often increased productivity [6]. Good agricultural practices have improved the performance of the agricultural environment by complying with basic environmental management practices, including conservation of land and water resources, rejection of prohibited pesticides and maintenance of primary forests [7]. 
According to Hafsah [8], partnership is a business strategy that is carried out with two or more parties within a certain period of time to gain benefits together with the principle of mutual need and mutual nurturing. There are several types of partnership patterns that have been implemented as follows: 1) nucleus-estate smallholder partnership, 2) sub-contract pattern 3) general trading patterns, 4) agency patterns, and 5) franchise patterns. Ruben \& Zuniga [7] stated that partnership introduces good agricultural practices for the production and post-harvest processes to improve the skills of smallholders and improve agricultural management. In addition, Bitzer et al. [9] indicated that the partnership also presents new resources for technological change in agricultural chains in developing countries where many farmers do not have access to adequate information and counseling. Manning \& Hagen [10] mentioned that partnership can also improve working conditions at the production level and put aside practices that cannot be accepted through the application of standards.

To compete in the international market, Timor Leste relies on coffee as a superior commodity that can be exported to increase foreign exchange for the country. Increasing export value and the volume of coffee exports will increase its competitiveness in the international market. Acharya [11] noted that commodities with a high level of comparative and competitive advantage have the potential and ease in increasing productivity to achieve a higher level of competitiveness. Countries that have a larger market share will increase product competitiveness in the international market and vice versa. A country is considered to have a comparative advantage in the production of certain goods if it has low relative cost in the production of that good compared to other countries.

Comparative advantage is the most widely used indicator for measuring a country's international trade performance. Data from the world top coffee export in 2017 showed that in surrounding Timor Leste's coffee producers in South East Asia (ASEAN), Vietnam ranked number 2 amounting to US\$3.5 billion and shared $10.7 \%$ of the world total export. Indonesia was in the $7^{\text {th }}$ rank worth at US $\$ 1.9$ billion and shared $3.6 \%$ from the world total. Meanwhile, Timor Leste ranked at $60^{\text {th }}$ position amounting at USS 18.4 million and contributed about $0.1 \%$ in the world market. Other coffee producing competitors are Thailand ranked at $90^{\text {th }}$ worth at US\$3.0 million and $0.01 \%$ of the word total and the Philippines was in the position of 118 , amounting to only US $\$ 112.00$ coffee export, and $0.0003 \%$ world total [12]. It can be seen from the previous data that Timor Leste is far way from large coffee producing countries such as Vietnam and Indonesia. On the other, Timor Leste coffee has an opportunity to compete with Thailand and the Philippines.

The problems of the current study are specified in the form of two questions. 1) What is the form of partnership between the group of the coffee farmers and the CCT as facilitating company like?; 2) To what extent Timor Leste coffee can compete with the neighboring coffee producing countries such as Vietnam, Indonesia, Thailand and Philippines? This study, firstly, describes the type of partnerships between coffee farmers and the CCT. Emphasis is given on the 
rights and obligations for both parties in the partnership to decide the type of partnership category. Secondly, the study examines the competitiveness of Timor Leste's coffee in the world market with selected producing countries.

\section{Research Method}

This study used an explorative approach using farming survey to find out the type of partnership between coffee farmers and the cooperative (CCT).The research area selected was Ermera District, Timor Leste (Figure 1). This location was selected as the district has the highest number of farmers-CCT partnership accounting for about 42 percent of the 24,000 CCT members. Ermera District is one of the districts located in the middle west of Timor Leste with an area of 746 square kilometers where 117,064 heads of population live [13]. Its capital is Gleno, which is located 30 kilometers to the west of the National Capital, Dili.

A purposive sampling method was used to select farmers as respondents. In the current study the respondents were selected from two groups; that is 50 farmers under the CCT partnership and other 50 farmers from non-partners of the CCT. The aim of selection is to compare coffee production under CCT and non CCT. Later in the discussion these respondents will be called as CCT farmers and non-CCT farmers respectively.

Primary data collection was carried out through interviews using questionnaires to the respondents and observations in the field in June-July 2018. The data obtained from interviews and observation included characteristics of coffee farmers, production in 2017, sales, size of holding, prices at the farm level. In addition, in-depth interviews to the wet process and coffee rehabilitation and dry coffee processing managers of CCT were carried out to find the rights and obligations between farmers and the company in the form of partnership. Comparison between CTT farmers and non-CCT was developed to find out advantages of farmers under the CCT partnership. On the other hand, secondary data were required to analyze the competitiveness of Timor Leste coffee to the selected countries. Data were obtained from the UN COMTRADE database for 2008-2016 and from the National Statistics of Timor Leste in 2008-2016.

The data were analyzed 1) descriptive qualitatively to identify the pattern of the partnership between farmers and the CCT in the forms of rights and obligations for both parties; and 2) using the Revealed Comparative Advantage (RCA)
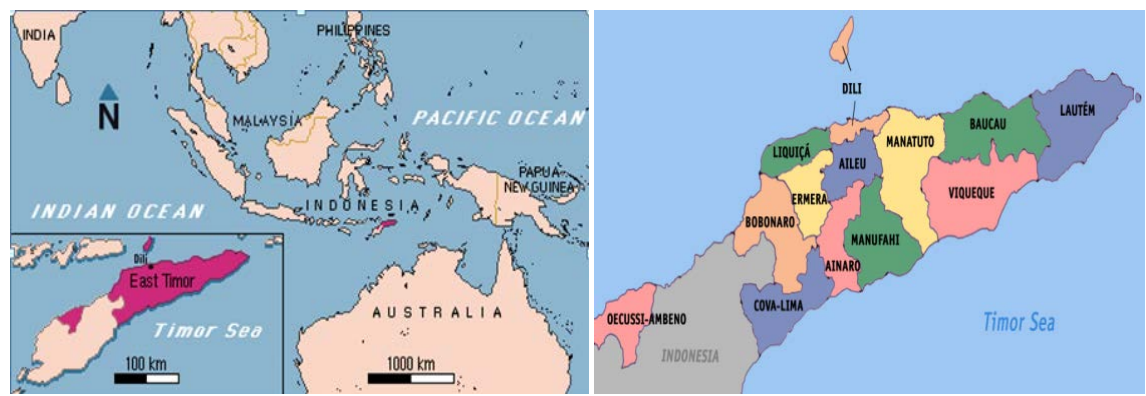

Figure 1. Location of the study. 
model Balassa [14] to find out the competitiveness of Timor Leste's coffee compared to selected countries. RCA has been commonly used to identify countries who are relatively close competitors in a given market [15] [16]. The World Bank [15] noted that RCA is an index that measures a country's revealed comparative advantage in the trade of a particular product/industry by the share of that product/industry in the country's total exports relative to the product/industry's share in the total world export. Formally, the index can be presented as:

$$
\mathrm{RCA}=\left(X_{i j} / X_{i n}\right) /\left(X_{r j} / X_{r n}\right)
$$

where:

$X_{i j}$ is total exports commodity $\mathrm{j}$ from country $I$;

$X_{i n}$ is total export all commodity from country $i$;

$X_{r j}$ is total export commodity $j$ from all countries (world);

$X_{r n}$ is total exports all commodities from all countries (world).

If the value of the index exceeds unity, it is interpreted that the country has a revealed comparative advantage. In other words, the industry's share in the country's total exports is greater than its share in the world trade. If the value is less than unity, the country is said to have a comparative disadvantage in the product. The RCA value of the product of a country is higher than one (RCA > 1 ), then its competitiveness in that product will be strong. If the RCA value of the product of a country is lower than one $(\mathrm{RCA}<1)$, then its competitiveness in that product will be weak.

In the current study, the Standard International Trade Classification (SITC) Revision 1 Coffee (071) published by the United Nations Organization, (UN COMTRADE) and the data prepared by the National Statistics Timor Leste were used to identify the RCA value of every country. This study intended to select Indonesia and Vietnam to see how far the competitiveness of large producing countries compared to Timor Leste's position. By the same time, two close amounts of coffee producing countries in South East Asian, namely the Philippines and Thailand, were selected to observe how far the product can be competitively exported. Hence four countries were selected in the analysis of RCA.

\section{Results and Discussion}

\subsection{Characteristics of Respondents}

\begin{tabular}{ccc}
\hline & Partner Farmers CCT & Non Partner Farmers \\
\hline Age & 41.94 year & 49.44 year \\
Number of Family members & 6.1 people & 6.22 people \\
Planting area (ha) & $1.22 \mathrm{ha}$ & 0.89 ha \\
Coffee Price & $0.45 / \mathrm{kg}$ & $0.30 / \mathrm{kg}$ \\
Total Production (year) & $1032.8 \mathrm{~kg} /$ year & $584.4 \mathrm{~kg} / \mathrm{year}$ \\
\hline
\end{tabular}

The average age of Coperativa Café Timor (CCT) partner farmers is 41.94 years 
with a range of 33 - 61 years and non-partner farmers averaging 49.44 years. Whereas the average level of education of CCT partner and non-partner farmers is elementary schools that range from elementary school to high school education. This shows that age and education factors are not an obstacle for farmers to cultivate coffee to help the family economy.

The average number of family members of CCT partner farmers is 6.1 people and non-partner farmers' average of 6.22 people. In general, coffee farming, both CCT and non-partner partner farmers, is the majority of families involved as laborers in the coffee production process. Family involvement is very helpful for farmers because farmers do not need costs for farmers' coffee commodity farming needs. Both partner farmers and non-partner partner's use outside labor but with a profit sharing system.

The average planting area of CCT partner farmers was 1.22 ha, whereas 0.89 ha for non-partner CCT farmers. The coffee farming from the CCT farmers, to some extent, is still maintaining the old coffee trees from generations. Nonetheless, under the CCT partnership coffee trees have been rehabilitated and replanted for better production. On the other hand, the majority of non-partner CCT farmers (around 80 percent) are still depending on old and poorly maintained coffee trees. The trees have been passed down from generation to generation since the Portuguese era ranging from 30 - 40 years old. This condition surely affects the coffee production and its quality.

In terms of production, the CCT farmers harvested at the average of $1032 \mathrm{~kg} / \mathrm{year}$ of red coffee beans, while $584.4 \mathrm{~kg} /$ year for non CCT farmers. In comparison, the CCT farmers were able to produce $846.56 \mathrm{~kg} / \mathrm{ha} /$ year whereas the non-CCT farmers produced $656.63 \mathrm{~kg} / \mathrm{ha} /$ year. It can be seen that the CCT farmers were able to produce about 29 percent higher of coffee beans than that of the non-CCT farmers. The higher production of the CCT farmers compared to the non-CCT is because the trees have been rehabilitated under the CCT program.

The type of coffee sold by the CCT farmers is in the form of red coffee beans as the company only demands for certain maturity of beans to be processed further to maintain the quality of the coffee. The average price of red coffee beans from the CCT to the partner farmers was US $\$ 0.45 / \mathrm{kg}$. This price was approved between partner farmers and the CCT. Meanwhile the non-CCT farmers received at US $\$ 0.30 / \mathrm{kg}$ on average. The non-CCT farmers usually sell their coffee beans to traders or at traditional markets in the form of varies coffee output both red coffee beans, dried coffee beans and others.

In comparison, the CCT farmers received 50 percent higher selling price than that of the non-CCT. Difference in selling price will bring to the difference of revenue for each farmer. The revenue is calculated from production multiplied by the selling price. The CCT farmers received US $\$ 380.95 /$ ha/year as revenue from the sale of red coffee beans. Meanwhile the non-CCT received only US\$197/ha/year. It is obvious that the CCT farmers had much higher revenue from the non-CCT farmers. Revenue of the CCT farmers is almost 100 percent higher than that of the non-CCT farmers. 


\subsection{The Cooperativa Café Timor (CCT) and Coffee Farmers Partnership}

The Cooperativa Café Timor (CCT) is a $100 \%$ Timorese owned cooperative involved in the processing and marketing of organic coffee on behalf of its producer members. The CCT was established in 2000 under the Timor Economic Rehabilitation and Development Project (TERADP), which was implemented by the National Cooperative Business Association of the USA (NCBA) from the USAID grant. Initially the program was developed by NCBA in cooperation with East Timor Center for Village Unit Cooperatives (PUSKUD) 1994 with the mission to develop organic coffee as an international market commodity for Timor Leste.

In line with the stated mission and vision, an agreement was signed between PUSKUD and NCBA to develop organic coffee by setting up an autonomous organic coffee division as a unit under PUSKUD Timor-Timur in 1995. This positive cooperation was important and eventually became a competitor to other coffee traders such as PT Batara Indra and PT Denok. Following independence for East Timor after the "popular consultation" on 30 August 1999, and by written agreement of the directors, PUSKUD changed its name and became the CCT. The goals of the project remain the same that is to improve the level of welfare of the coffee growers; to introduce marketing chains to the farmers; and to contribute to the planning and policy development for a commodity which supports the economy of the people of Timor Leste.

CCT has 24,000 members who are spread throughout the region in Timor Leste and in the form of 500 farmer groups. Coffee purchased by the CCT is always in the form of red beans to guarantee the quality and in turn good prices offered to the farmers. To a large extent (90 percent) of CCT coffee is processed into coffee beans for export and other 10 percent is processed into ground coffee sold for domestic market. The CCT absorbs about 65 percent of Timor Leste's coffee export. All CCT coffee is sold with organic certification of Control Union certificate. It is about 70 - 80 percent of CCT sales also attract a "Fair Trade" premium. There is about $60 \%$ of CCT coffee is currently sold to the Starbucks coffee company, with whom CCT have developed a special relationship under the Starbucks CAFÉ (Coffee and Farmer Equity) practices program. CCT is now a certified supplier of coffee to Starbucks.

Figure 2 shows the partnership pattern that exists between coffee farmers and

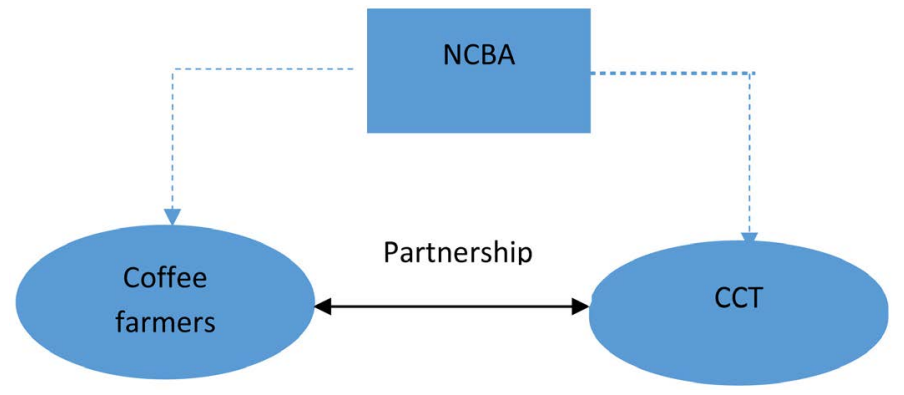

Figure 2. The partnership link between coffee farmers and the CCT. 
the CCT. The CCT gets supports from the National Cooperative Business Association (NCBA) to trade coffee produced in Timor Lestein the international market. The NCBA is the United States company which has been a partner of the CCT to develop organic coffee as an international market commodity for Timor Leste. The NCBA together with the CCT also manage trainings to farmer groups in the implementation of GAP and to maintaining organic certifications by Control Union Certification Production Standards and Regulation (USDA Organic). Certification from the Control Union has been accepted worldwide; hence it leads to increase bargaining position of Timor Lesteorganic coffee in the international market.

At the farm level, farmers have to obey certain agreements with the CCT that have been set up by both parties. These include rights and obligations between farmers and the CCT to attain benefits for all stakeholders. Rights and obligations of coffee partnership in Timor Leste are presented in the following section.

\subsection{Rights and Obligations of Coffee Partnership}

Table 1 presents rights and obligations between the CCT and the farmers. As can be seen from the table, both parties have incentives to obey their agreements including prices, certification, technical assistance and supervision.

Looking at the rights and obligations between the CCT and farmers, it can be categorized that the pattern of the partnership is a nucleus estate and small-holder partnership. According to Hafsah [8], the nucleus-estate partnership is a pattern of relations between business partner groups as plasma and the core companies that are partners. One example of this partnership is where the nucleus company provides land, production facilities, technical guidance, production management, processing and markets for the products.

Based on the rights and obligations, the CCT must guarantee a definite and sustainable market for the partner farmers, provide practical land for fostering

Table 1. Rights and Obligations of CCT and coffee farmer groups.

\begin{tabular}{|c|c|c|}
\hline Partners & Obligations & Rights \\
\hline CCT & $\begin{array}{l}\text { - Ensure market certainty } \\
\text { - Provide guidance and mentoring to } \\
\text { farmers } \\
\text { - Provide land for demonstration plot } \\
\text { to be seen by farmers } \\
\text { - Provide tools and production } \\
\text { facilities to farmers } \\
\text { - Facilitate farmer groups to obtain } \\
\text { and maintain organic certificate }\end{array}$ & $\begin{array}{l}\text { - Obtain red coffee beans from partner } \\
\text { farmers } \\
\text { - Reject coffee from farmers who do not } \\
\text { apply organic practices according to the } \\
\text { CCT and Control Union standards. }\end{array}$ \\
\hline Coffee farmers & $\begin{array}{l}\text { - Sell red coffee beans to CCT } \\
\text { - Follow the rules for organic } \\
\text { cultivation applied by the CCT } \\
\text { - Willing to be supervised and } \\
\text { controlled by CCT, NCBA, and } \\
\text { Control Union }\end{array}$ & $\begin{array}{l}\text { - Obtain prices according to the agreement } \\
\text { - Obtain a definite market guarantee } \\
\text { - Obtain technical guidance and assistance } \\
\text { - Obtain tools and production facilities } \\
\text { - Obtain and maintain organic certificate } \\
\text { - Obtain free health treatment to some } \\
\text { extent }\end{array}$ \\
\hline
\end{tabular}


coffee farmers when practicing in the field, provide assistance with tools and production facilities for farmers. The CCT also provides guidance and technical assistance to farmers and facilitate farmers to obtain and maintain organic certificate. On the other hand, as small-holder farmers, it is compulsory for them to sell red coffee beans to CCT. Farmers are also obliged to cultivate coffee organically in accordance with the standard of guidance provided by the CCT and ready to be controlled by the CCT and Control Union. Certificates provided to farmer groups, the CCT upon attainment of necessary standards, provide assurance to customers that the product is organically grown. To keep the certificate, producers must document at least three years of operation without synthetic chemicals, grow the crop according to organic Control Union Certification standards, and pass annual certification based on field inspections, record keeping, and processing operations.

The right that can be received from the nucleus partner is that farmers obtains a price agreed upon, a definite market guarantee, technical guidance and assistance such as the technique of cutting coffee or rehabilitating coffee and proper cultivating coffee and correctly based on the GAP. The profitability of organic farms depends on the higher prices that their products command in the marketplace.

Organic production is environmentally sound because it applies on-farm good agricultural practices (GAP) that exclude all synthetic off-farm inputs and off-farm good handling practices (GHP). GAPs minimize soil and water degradation, whereas GHPs help maintain the organic integrity and vital qualities of products. Budiasa [17] addressed that appropriate technology and traditional farming methods applied by farm groups, with support from the government, have made the organic farming system socially acceptable.

In addition, farmers get assistance with tools and production facilities such as machetes, crowbars, hoes, boots, tarps, seeds and to some extent of organic fertilizers from the CCT. Partner farmers are also assisted by the CCT to obtain organic certificates from Control Union Certification Production Standards and Regulation (USDA Organic). In addition, the company's right is to get red coffee beans from partner farmers and not accept coffee sales from farmers if it is proven that the coffee is not organic or farmers violate the rules of organic coffee cultivation.

The CCT farmers obtain clear benefits from higher coffee prices compared to non-CCT members. Meanwhile the CCT obtains stable supply of red beans from the members. The CCT is not only concerned with the coffee production system, but also to the health of the farmers and their family. The CCT provides healthcare clinics at the selected producing districts in Timor Leste.

\subsection{Competitiveness of Timor Leste Coffee}

Coffee competitiveness from selected producing countries using RCA index is presented in Table 2 . It shows that countries with the RCA value higher than 1 
Table 2. Revealed Comparative Advantage (RCA) of selected coffee producing countries.

\begin{tabular}{cccccc}
\hline \multirow{2}{*}{ Year } & \multicolumn{5}{c}{ Country } \\
\cline { 2 - 6 } & Vietnam & Indonesia & Philippines & Thailand & Timor Leste \\
\hline 2008 & 20.485 & 4.740 & 0.023 & 0.296 & 0.586 \\
2009 & 15.515 & 3.935 & 0.024 & 0.385 & 0.483 \\
2010 & 13.304 & 3.174 & 0.015 & 0.394 & 0.493 \\
2011 & 12.166 & 2.681 & 0.014 & 0.310 & 0.396 \\
2012 & 14.113 & 3.663 & 0.007 & 0.377 & 0.417 \\
2013 & 11.445 & 4.225 & 0.005 & 0.452 & 0.537 \\
2014 & 11.131 & 3.663 & 0.019 & 0.457 & 0.466 \\
2015 & $($ “c0”) & 4.697 & 0.021 & 0.391 & 0.441 \\
2016 & 7.887 & 4.163 & 0.022 & 0.249 & 0.415 \\
\hline
\end{tabular}

Source: Data processed from UNCOMTRADE [21] and National Statistic Timor Leste [22] [23] (0") No data.

(RCA $>1$ ) are Vietnam and Indonesia. Vietnam is the leading coffee producing country in ASEAN while Indonesia has the second position. Previous studies [18] [19] have mentioned that both countries have strong comparative advantages in ASEAN. A study by Rianita [20] also confirmed that Vietnam and Indonesia are two major coffee producing countries. In the study it also revealed that the Philippines and Thailand are far from the competitiveness of Vietnam and Indonesia.

The RCA value of Timor Leste, the Philippines and Thailand was less than 1 $(\mathrm{RCA}<1)$, showing that their coffee market share viewed from their total export was smaller than their total export of all commodities market share from their country. Calculation of the RCA of Timor Leste coffee from 2008 to 2016 shows an average value of RCA $<1$, which means that Timor Leste is unable to compete with Vietnam and Indonesia. However, Timor Leste is able to compete with the Philippines and Thailand (Table 2).

The smaller competitiveness of Timor Leste coffee in the RCA calculation is due to the calculation of RCA only looking at the quantity of coffee production from each country that is influenced by the export value. It does not count for the quality of coffee demanded in the international market. In terms of the world coffee market, Timor-Leste is a small country coffee export. Timor Leste is the smallest coffee producer in the world with a total supply below 0.1 percent, however Timor Leste coffee has a competitive advantage as one of the organic coffee producers in the world.

The most popular coffee from Timor Leste is Timor Hybrid, which is a natural cross-breed of Arabica and Robusta coffee varieties, recognized in the international market as high-quality organic coffee. The price premium for organic coffee and the biggest growth is in the premium coffee sector of the market, Timor-Leste will concentrate on retaining its niche as a producer of quality organic 
coffee. Integrated pest management techniques, such as cultural control, plant resistance, mechanical control and biological control, will be used to achieve and maintain organic certification [24].

The partnership of coffee farmers and CCT has proved to increase coffee competitive advantages of Timor Leste in the world market. Since NCBA's entry into the market in 1994, they have been selling to international buyers and roasters in the US and Europe such as Hollands, Royal, Dunkin' Donuts and the Seattle-based cafe chain, Starbucks who purchase two-thirds of the crop [25] [26]. Starbucks is the largest coffee shop company in the world in collaboration with various farmers, cooperatives and suppliers. There are around 300,000 coffee farmers in 30 countries around the world as suppliers of coffee to Starbucks. The locations centre of Starbucks coffee suppliers in various countries include Costa Rica, Honduras, Nicaragua, El Salvador, Panama, Guatemala, Mexico, Kigali (Rwanda), Mbeya (Tanzania), Manizales (Colombia), Yunnan (China) and Sumatra (Indonesia). Starbucks only buys high-quality organic coffee beans. Starbucks visits farmers and coffee suppliers annually to ensure that the coffee sold by suppliers is organic and of high quality (Starbucks, 2017).

The CCT registered as a Fair Trade buyer of coffee, The CCT's coffee is internationally certified organic, and the product accredited by the international Fairtrade Labelling Organization (FLO), as CCT has conducted, it offers further premiums for a limited volume of product. Timor Leste coffee has enabled to gain access to the niche organic market. CCT have pioneered the development of organic certification for Timor-Leste's coffee. Only in more recent years has the emerging cooperative organisation under the USAID sponsored NCBA and CCT begun to pay a premium for better organically certified quality cherry, and to improve the quality of local processing. In fact, CCT is now the largest single-source supplier of organic coffee in the world. Revenue from the Fair trade Premium has been invested to improve the working and living conditions of farmers and their families and invested in the diversification of local income earning opportunities [25].

\section{Conclusion}

Results of the study from the previous discussion can be concluded as follows: 1) The partnership established between the coffee farmers and the CCT referred to the nucleus-estate and smallholder partnership, both partners gain benefits from the rights and obligations; 2) Using the RCA analysis, Vietnam and Indonesia are major coffee players in the ASEAN, while Timor Leste is able to compete with the Philippines and Thailand. Nevertheless, Timor Leste has a competitive advantage in exporting organic coffee in the world market.

\section{Recommendation}

Therefore, in order to improve the competitiveness of the coffee farms in Timor Leste, it is suggested that 1) the assistance from the government and the CCT, as 
their partner, to the coffee farmers are highly expected to solve different problems they face; 2) The result of analysis shows that the competitiveness of the coffee produced by Timor Leste is still weak in the international market, as the market share of the coffee produced in Timor Leste in the international market is much smaller than that of the coffee produced in Vietnam and Indonesia and the other parts of the world. The cultivation of new types of coffee seedlings, the elimination of the old coffee trees, the application of modern technology, and expansion of the coffee plantation will increase the coffee produced in the future.

The disadvantage of this study is that it does not analyze coffee organically because of limited data and only analyzes coffee competitiveness in general, needs to analyze the competitiveness of organic coffee specialty coffee by using analysis Policy matrix (PAM) analysis in the international market in the future to make it more knowing the competitiveness of Timor Leste organic coffee on the international market, because in this study only looked at coffee competitiveness in general because of the limited availability of data from the Timor Leste, it needed to involve more farmers and partners to produce more information, because in this study only 50 partner farmers and 50 non-partners were involved.

\section{Acknowledgements}

In this opportunity, I would like to thank Mr. Fernando Santana, the Director of Geral Café e PlantasIndustriais, and Mr. Egidio Fernando Amaral, the Director of the National Agribusiness, the Ministry of Agricultural Affairs of Timor Leste, Mr. SistoPiedadeMonis, the General Manager of the CCT, Mr. LomelinoSalsinha, Manager of the Wet Process and Coffee Rehabilitation of the CCT, Mr. Eusebiu Dias Quintas, Manager of the Dry Coffee Process of the CCT, staff members of the CCT (Rozilia, Zelia, Esterlita), the coffee farmers both as the partners and non-partners of the CCT in Ermera District, Timor Leste.

\section{Conflicts of Interest}

The authors declare no conflicts of interest regarding the publication of this paper.

\section{References}

[1] Asian Development Bank ADB (2015) Paper-Free Trade for Smallholder Farmers. A Pilot Study of a Coffee Association in the Lao People's Democratic Republic. ADB Southeast Asia Working Paper Series.

[2] Krishnan, S. (2017) Sustainable Coffee Production. Oxford Research Encyclopedia, Environmental Science. Development of the Global Strategy for Conservation of Coffee Genetic Resources. https://doi.org/10.1093/acrefore/9780199389414.013.224

[3] Lewin, B., Giovannucci, D. and Varangis, P. (2004) Coffee Markets: New Paradigms in Global Supply and Demand. The International Bank for Reconstruction and Development Agriculture and Rural Development Department, World Bank, Washington DC. https://doi.org/10.2139/ssrn.996111 
[4] Menisterio Agricultra e Pescas Republica Democratica de Timor Leste (MAP) (2017) Coffee Production and Farmers' Household Production Coffee. National Directorate of Plantation and Coffee Industry (NDPIAC) Timor Leste.

[5] Henriques, P.D., Lucas, M.R., Carvalho, S.L.M. and de Deus, C. (2002) Coffee Value Chain in Timor Leste. Chapter XX.

[6] Potts, J., Meer, J.V. and Daitchman, J. (2010) The State of Sustainability Initiatives Review 2010: Sustainability and Transparency. International Institute for Sustainable Development (IISD) and the International Institute for Environment and Development (IIED), Genève.

[7] Ruben, R. and Zuniga, G. (2011) How Standards Compete: Comparative Impact of Coffee Certification Schemes in Northern Nicaragua. Supply Chain Management. An International Journal, 16, 107-109. https://doi.org/10.1108/13598541111115356

[8] Hafsah, J. (2000) Kemitraan Usaha (Business Partnership). Cetakan Kedua. Pustaka Sinar Harapan Jakarta. (In Bahasa Indonesia).

[9] Bitzer, V., Helmsing, J.H. and Linde, V.V. (2011) Partnering to Facilitate Smallholder Inclusion in Value Chains. In: Value Chains, Social Inclusion and Economic Development. Contrasting Theories and Realities, Routledge, London and New York.

[10] Manning, S. and Hagen, V.O. (2010) Linking Local Experiments to Global Standards: How Project Networks Promote Global Institution-Building. Scandinavian Journal of Management, 26, 339-414. https://doi.org/10.1016/j.scaman.2010.09.003

[11] Acharya, R.C. (2008) Analyzing International Trade Patterns: Comparative Advantage for the World's Major Economies. Journal of Comparative International Management, 11, 33-53.

[12] World Top Export (2017) List of Coffee Exporting Countries. http://www.worldstopexports.com/coffee-exports-country

[13] Timor-Leste Population and Housing Census (2010) Copyright Government of Timor-Leste 2010.

[14] Balassa, B. (1965) Trade Liberalization and Revealed Comparative Advantage. The Manchester School of Economics and Social Studies, 33, 99-123.

https://doi.org/10.1111/j.1467-9957.1965.tb00050.x

[15] World Bank (2010) The Trade Indicators Utility Allows You to Calculate Various Useful Trade Indices Using the Underlying UN COMTRADE Data. https://wits.worldbank.org/WITS/WITS/WITSHELP/Content/Utilities/e1.trade_ind icators.htm

[16] French, S. (2014) Revealed Comparative Advantage: What Is It Good For? http://research.economics.unsw.edu.au/sfrench/documents/French_RCA.pdf https://doi.org/10.2139/ssrn.2525827

[17] Budiasa, I.W. (2014) Organic Farming as an Innovative Farming System Development Model toward Sustainable Agriculture in Bali. Asian Journal of Agriculture and Development, 11, 65-76.

[18] Purnamasari, M., Wen, H.C. and Hanani, N. (2014) Competitiveness of Indonesian Coffee on the World Market: Using Selected Indicators. AGRISE, 14, 58-66.

[19] Suprayogi, B.M., Arifin, Z. and Mawardi, M.K. (2017) Analisis Daya Saing Ekspor Kopi Indonesia, Brazil, Kolombiadan Vietnam (Analysis of Coffee Export Competitiveness). Jurnal Administrasi Bisnis, 50, 190-194. (In Bahasa Indonesia)

[20] Rianita, G.A.M.D. (2014) Analisis Komparasidan Daya Saing Ekspor Kopi Antar Negara ASEAN Dalam Perdagangan Bebas ASEAN Tahun 2002-2012. (Analysis 
Comparability and Competitiveness of Coffee Export between ASEAN Countries in ASEAN Free Trade). Jurnal Ekonomi Pembangunan, 1, 145-158. (In Bahasa Indonesia)

[21] United Nations Comtrade Database (UN Comtrade) (2018) Extract Data. https://comtrade.un.org

[22] National Statistic Timor Leste (2010) External Trade Statistic Annual Report 2010. Ministério das Finanças. Direcao-Geral de Analise e PesquizaDirrecao Nasional de Estatistica.

[23] National Statistic Timor Leste (2016) External Trade Statistic Annual Report 2016. Ministério das Finanças. Direcao-Geral de Analise e PesquizaDirrecao Nasional de Estatistica.

[24] Menisterio Agricultura e Pescas Republica Democratica de Timor Leste (MAP) (2011) Timor Leste Strategic Development Plan 2011-2030.

[25] Ministry of Agriculture and Fisheries, Timor-Leste (MAF) (2009) Coffee. Directorate of Industrial Crops and Agribusiness. Commodity Profile Series No 9. Version 1.

[26] Starbucks (2017) Newsroom.

https://news.starbucks.com/news/starbucks-debuts-rare-east-timor-single-origin-co ffee 


\section{Appendix}

\section{DOCTOR PROGRAM OF AGRICULTURE SCIENCE \\ FACULTY OF AGRICULTURE \\ UDAYANA BALI UNIVERSITY}

COMMODITY SURVEY QUESTIONARY

COFFEE IN TIMOR LESTE

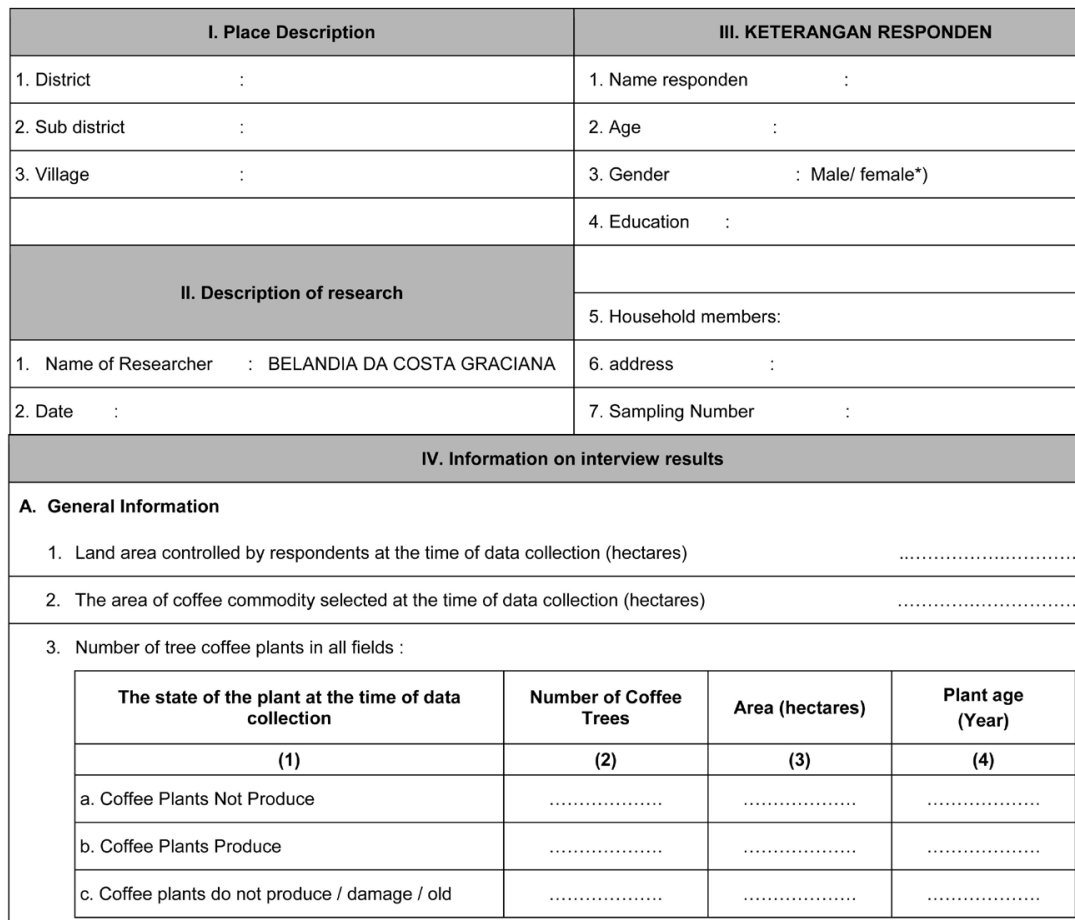

4. The form of primary (commonly sold) coffee production of farmers

5. Average selling price of ordinary primary coffee production (IDR / $\mathrm{kg}$ ) $\ldots$

6. The average age of coffee trees that farmers cultivate

7. Total production every year

8. Use of organic fertilizers / prices

9. Transportation costs

10. labor used and labor costs

12. facilities used in coffee production and prices

13. Price of coffee seeds

14. Subsidies from the Government (What?)

$\ldots$

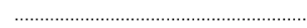

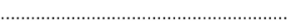

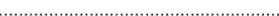

$\ldots$

$\ldots$

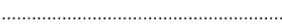

V. ADDITIONAL INFORMATION 
PARTNERSHIP PATTERN

1) The form of coffee sold? Fruit? Seeds? Powder?

2) Where do you sell coffee?

3) Which partner do you partner with?

4) Impact of partnerships on coffee farmers?

5) When to start partnering with?

6) Benefits gained from the partnership?

7) Agreement, Mou \& Agriment contract?

8) Socia Bebefit?

9) Marketing channels or coffee distribution from farmers?

10) Farmers in partnership have organic certificates?

11) Costs for organic certificates? 